AGH DRILLING, OIL, GAS • Vol. 30 • No. $1 \cdot 2013$

http://dx.doi.org/10.7494/drill.2013.30.1.311

\title{
ABSTRACT
}

\author{
J. Wesley Burnett*
}

\section{HYDRAULIC FRACTURING AND U.S. WATER POLICY}

The recent boom in the development of natural gas from shale is a game changer for U.S. domestic energy. Large domestic reserves of shale gas reduce dependency on foreign producers, as is currently the case for crude oil. The U.S. Energy Information Administration (EIA) estimates that the U.S. contains approximately 500 trillion cubic feet of unproved technically recoverable resources from shale gas. At current rates, that is enough gas from shale alone to supply the entire country for approximately twenty-one years.

The large increase in shale gas development has been made possible through the development of two principle technologies: horizontal drilling and high-volume, hydraulic fracturing (HVHF) fluid. Horizontal drilling or directional drilling allows producers to access far more natural gas from relatively thin shale deposits within the earth. HVHF involves injecting a large volume mixture of water, sand, and other chemicals deep into the earth. The high pressure from the fluid causes shale rock formations to fracture so that natural gas can be released and extracted. HVHF fluid is mostly composed of water (generally ninety-eight to ninety-nine percent) and can contain some potentially hazardous (and possibly carcinogenic) chemicals including benzene and lead.

The contention over hydraulic fracturing surrounds public fears over contamination of drinking water sources. This sentiment was captured in the anti-fracking film by Josh Fox called Gasland - the film received a 2010 special jury prize for a documentary at the Sundance Film Festival and was nominated by the Academy Award for Best Documentary in 2011. According to a recent report from the Natural Resource Defence Council (2012), HVHF fluid can contaminate drinking water on the surface or below the ground surface. Potential surface contamination can occur because of: (1) spills or leaks from storage tanks, valves, or transportation pipes, or (2) mismanagement of fracturing waste or "flowback" fluid which is often stored in surface pits. Contamination to below ground surface can occur due to (1) migration of fluid to neighboring oil or gas wells, (2) improper construction, cementing, and casing of the well, and (3) migration of fluid to other natural fracture networks.

* West Virginia University, Morgantown, West Virginia, USA 
In addition to potential contamination, HVHF fluid also requires large volumes of water taken from fresh water sources, and if the water is contaminated it cannot be returned to water bodies without extensive treatment. When a well is injected with HVHF fluid some of it returns to the surface as flowback, but not all fracturing fluid injected into a geologic formation are recovered. If the flowback fluid is contaminated then it may need to be returned underground using a permitted underground injection well.

The natural gas industry often claims that there is no evidence of contamination to freshwater aquifers. For example, Rex Tillerson, chief executive of ExxonMobil, offered the following statement at a recent Congressional hearing on drilling: "There have been over a million wells hydraulically fractured in the history of the industry, and there is not one, not one, reported case of a freshwater aquifer having ever been contaminated from hydraulic fracturing. Not one." Urbina (2011) contends that the lack of documented cases exist because the industry often settles suspected cases through lawsuits with private landowners, in which case the details of such cases are sealed from public disclosure. In fact, a U.S. Environmental Protection Agency (EPA) 1987 Congressional report documented a case of contaminated well water from HVHF fluid in West Virginia. Additionally, a Duke University study found that drinking water methane concentrations were seventeen times higher in active drilling locations.

What is unclear in the U.S. at this point is the nation's system of federalism in regulating HVHF. For example, it is not clear what role, if any, the EPA will play in regulating this practice. Much to the ire of environmentalists, the practice of hydraulic fracturing is largely exempt from the Safe Drinking Water Act (SDWA) as superseded by the Environmental Policy Act of 2005. Legislation, dubbed the FRAC (fracturing responsibility and awareness of chemicals) act, was introduced to both houses of Congress to enable the EPA to obtain jurisdiction over hydraulic fracturing under the SDWA; however, to date no major legislation has passed in either house. The EPA's ability to regulate HVHF under the Clean Water Act is limited to the disposal of flowback into surface waters in the U.S. Therefore, the regulation of HVHF has largely been relegated to state and local governments.

The EPA historically has granted "primacy" for some states to oversee and regulate the disposal of hazardous waste, such as flowback, into injection wells within their own borders. The problem of course is that some states have not been granted primacy. For example, in the Marcellus shale region Pennsylvania does not have primacy, so the federal government has to sign off on all new injection wells in the state which causes delays and red tape. Further, Pennsylvania does not have many suitable geological formations for injection wells. Therefore, a large portion fracturing waste fluid from Pennsylvania is transported to New York, Ohio, and West Virginia for disposal. A potential problem for the future is that the drilling and fracturing industries are exempt from federal hazardous waste disposal laws, so fracturing waste is being injected into wells with less stringent oversight.

Many critics argue that environmental regulations imposed by the federal government would be much stricter than state-level enforcement. Critics have argued that the SDWA provides the EPA with leverage against states' inaction in protecting water sources. In the absence of federal legislation, some fear a "race to the bottom" in which individual states may 
purposively impose lax environmental regulations to attract natural gas development. The justification for environmental regulations under federal control "reflect commonly understood collective action problems, including negative environmental externalities, resource pooling, the 'race to the bottom,' uniform standards, and the 'NIMBY' (not in my back year) phenomenon." What is clearly needed in this case is a model of "cooperative federalism" in which the federal government offers some guidance in the potential environmental impacts from shale gas development, but leaves regulation to local governments to provide a more comprehensive, protective, and accountable regulation of the industry.

The U.S. will likely be the bellwether for other countries as Germany, Hungary, Romania, Poland, China, and Australia are participating in discussions regarding the application of hydraulic fracturing to extract their shale gas reserves. How will the policy debate in the U.S. unfold? It is difficult to tell. Perhaps Benkin (1992) states it best: “... the choice of regulatory forum often seems to determine the outcome of the controversy. That may explain why Americans have traditionally shed so much metaphorical and genuine blood deciding what are essentially jurisdictional disputes between governmental institutions." 